\title{
THE PUBLIC SPHERE 50 YEARS LATER: PUBLIC SPHERE AND MASS MEDIA IN JÜRGEN HABERMAS
}

\author{
In honor of the 50 years of The Structural Transformation \\ of the Public Sphere ${ }^{1}$
}

Tradução de Jorge Adriano Lubenow ${ }^{*}$

"The Adorno's critique of mass culture should be continued and rewritten" (Habermas, 1985).

“As before, Adorno's critique of the culture industry is the correct key" (Habermas, 2008).

\begin{abstract}
The paper explores the relationship between public sphere and mass media in Habermas bibliographic corpus in the 50 years that separate us from Strukturwandel der Öffentlichkeit (1962). The aim of this paper is to show that, differently from some critical studies, it is not an investigative gap - absence, abandon or non exploitation of the topic - but a secondary approach, implicit; the
\end{abstract}

\footnotetext{
${ }^{1}$ This paper was originally written in Portuguese as "A esfera pública 50 anos depois: esfera pública e meios de comunicação em Jürgen Habermas”, and published in: Revista Transformação (UNESP), v.35, n.3, 2012, pp. 189-220.

* Professor Adjunto I de Filosofia do DFE e do Programa de Pós-Graduação em FilosofiadaUFPB.m@il: jlubenow@hotmail.com
}

Problemata: R. Intern. Fil. Vol. 03. No. 02. (2012), pp. 228-274 ISSN 2236-8612 DOI: http://dx.doi.org/10.7443/problemata.v3i2.15110. 
secondary approach of the theme is related to Habermas's original pessimistic position about the negative influence of mass media in the depoliticization of the public sphere; Habermas's pessimism about the negative effects of mass media maintains an internal connection to the original orientation of Adorno's critique of mass culture. This means that, despite reformulations and new diagnosis, Habermas's skeptical position about the democratic potential of mass media in public sphere re-politicization seems not to have changed in its foundations in these 50 years.

Keywords: Jürgen Habermas, public sphere, mass media, depoliticization.

\section{Introduction}

This paper discusses the internal relation between the themes "public sphere" and "mass media" of Habermas' literature in these 50 years that separate us from Strukturwandel der Öffentlichkeit (1962). The central theme of this work about public sphere is the subversion of the principle of public criticism (Öffentlichkeit) in manipulative publicity (Publizität), and the consequent depoliticization of the public sphere operated by state interference and mass media influence. Strukturwandel der Öffentlichkeit conclusion shows that the public sphere and the mass media are intrinsically linked: mass media are responsible for the depoliticization of the public sphere and the engendering of mass consumption. The public sphere, a space where there are discussions to the formation of public opinion (critical sense), goes through changes and, thus, a new connotation (manipulative sense). The manipulated public sphere is not the space where emancipatory rationality must happen. This negative diagnosis - the subversion of the critical principle of public sphere in a depoliticized public sphere, infiltrated by the power and dominated by the mass media - showed the structural problems of a public sphere unable to be a criterion of rational regulation of existing conflicts and, with it, it cannot be an effective normative basis for a theory of democratic legitimacy, in which the public sphere is the key concept. 
However, despite the strong emphasis on the mass media effects in the decline of the public sphere, despite reformulations of $1990,{ }^{2}$ and despite Habermas mentioning the theme of media regulation thirty years latter in Faktizität und Geltung (1992), ${ }^{3}$ this relation - public sphere and mass media - remained not thematized in a systematic way in the main latter writings, at least until $2006 .{ }^{4}$ What gained emphasis were the legitimacy problems resulting from a public sphere dominated by the ideological and technocratic power of science, ${ }^{5}$ the legitimacy crisis of the interventionist state ${ }^{6}$, and the influences of law $^{7}$, religion ${ }^{8}$ and international politics ${ }^{9}$ in the public sphere. That is, while the theme of state intervention was strengthened in the follows main political writings, the theme of mass-media remained implicit, latent. ${ }^{10}$

Thus, what is interesting to ask is: why did this theme of mass media and its relation with the public sphere, so central at the first work of Habermas, remain secondary for almost all subsequent literature? Why did this theme remain minor in latter writings, despite the expectation, however remote, of repoliticization of the public sphere through the re-democratization of mass-media at the

\footnotetext{
${ }^{2}$ Habermas, Strukturwandel der Öffentlichkeit, “Neues Vorwort”, 1990.

${ }^{3}$ Habermas, Faktizität und Geltung, p. 455.

4 Habermas, "Political communication in media society", in Communication Theory, 16/4, 2006, p. 411-26.

${ }^{5}$ Technik und Wissenchaft als "Ideologie", 1968.

${ }^{6}$ Legitimationsprobleme im Spätkapitalismus, 1973; Theorie des kommunikativen Handelns, 1981.

${ }^{7}$ Faktizität und Geltung, 1992; Die Einbeziehung des Anderen, 1996.

${ }^{8}$ Zwischen Naturalismus und Religion, 2005.

${ }^{9}$ Die Einbeziehung des Anderen, 1996; Die postnationale Konstellation, 1998; Zeit der Übergänge, 2001; Der gespaltene Westen, 2004; Ach Europa, 2008; Zur Verfassung Europas, 2011.

${ }^{10}$ As I showed in another moment: Lubenow, A categoria de esfera pública em Jürgen Habermas.[The category of public sphere in Jürgen Habermas]. João Pessoa: Manufatura, 2012, “Conclusão”, p. 133-136.
} 
conclusion of Strukturwandel der Öffentlichkeit? ${ }^{11}$ Why Habermas's disinterest in exploring the second cause of the depoliticization of the public sphere and not "update" their investigations on the relation between political public sphere and mass media? Why does not Habermas emit position on the secondary character of a theme that, on the contrary, proves to be so important and empirically relevant in the context of emergency and growth of new forms of midiatic communication? Why has not Habermas issued a more accurate judgment about the democratic role of the media, or how they could create conditions for the exercise of discussion and criticism in the public sphere? Not exploring this problem means Habermas' suspicion in relation to the democratic potential of mass media to contribute to the re-politicization of public sphere? If this is the case, why did not Habermas elaborate a more systematic critic to the democratization deficit of mass media? May this latency be associated with Habermas' pessimism about the democratic potential of mass media? Finally, in which sense does this pessimistic position maintain the proximity of Habermas from the original position of the Adorno's critique of mass culture?

Some critics point an investigative lack in Habermas, suggesting an absence of discussion about the role of mass media in the political public sphere; that, despite the emphasis in the mass media, this perspective of approaching would have been abandoned, or remained unexplored. For Luke Goode, it is curious that, given the explosive consequences attributed by Habermas to the mass printing in his early work, mass media have remained so glaringly undertheorized in his work overall. ${ }^{12}$ For Douglas Kellner, Habermas neglected the crucial role of mass media and new technologies in the structure and activity of contemporary societies; he failed to explain precisely the institutional and normative role of the media, giving a

\footnotetext{
11 Habermas, "Ein Interview mit New Left Review", in Die Neue Unübersichlichkeit. Suhrkamp, 1985, p. 245.

${ }^{12}$ Goode, Jürgen Habermas, democracy and public sphere, p. 142, footnote 7.
} 
character limited to the examination of the procedural and deliberative democracy, focusing only on the lifeworld and civil society; in short, Habermas would not have theorized the role of mass media in contemporary public sphere. ${ }^{13}$ For Nicholas Garnham, the habermasian concept of public sphere, despite offering an important point of departure for the study of mass media and democratic politics, failed to solve the problem about how to build democratic responsibility systems integrated with large-scale systemic ways that occupy the same social space where economic and political decisions impact. ${ }^{14}$

${ }^{13}$ Kellner, "Habermas, the public sphere, and democracy: a critical intervention”, in Hahn, Perspectives on Habermas, pp. 274-79.

${ }^{14}$ Garnham, Nicholas. "The media and the public sphere”, in Calhoun, Habermas and the public sphere, p.371. For other critical comments, see: Rodney Benson, "Shaping the public sphere: Habermas and beyond", in American Sociologist, n.40, 2009, 175-197; Bernhard Peters, Der Sinn von Öffentlichkeit. Suhrkamp, 2007, Parts II and III; Felicitas Söhner. Entwicklung der Massenmedien und Strukturwandel der medialen Öffentlichkeit bei Habermas. GRIN Verlag/FernUniversität Hagen, 2007; Pauline Johnson, Habermas: rescuing the public sphere. Routledge, 2006; Sérgio Costa, "Der Kampf um Öffentlichkeit: Begrife, Akteure, politische Dynamiken”, in Jahrbuch Lateinamerika. Medien und ihre Mittel, n. 28, 2004, p. 13-31; Nick Crossley \& John M. Roberts, After Habermas: new perspectives on the public sphere, Blackwell, 2004; Hauke Brunkhorst, "Critical Theory and the analysis of contemporary mass society", in Rush, The Cambridge Companion to Critical Theory. Cambridge Univ. Press, 2004, p. 248-279; H. Brunkhorst, Globalisierung und Demokratie. Wirtschaft, Recht, Medien. Suhrkamp, 2000, cap.3; Carl Sunstein, "Das Fernsehen und die Öffentlichkeit”, in Wingert \& Günther, Die Öffentlichkeit der Vernunft und die Vernunft der Öffentlichkeit, 2001, p. 678-701; J. B. Thompson, Media and modernity. Stanford Univ. Press, 1995; Kenneth Baynes, "Communicative ethics, the public sphere and communication media", in Critical Studies in Mass Communication, n.11, 1994, p. 315-326; John Peters, "Media ethics and the public sphere", in Communication, n.12, 1991, p. 197-215; J. Keane, The media and democracy. University of Westminster, 1991; P. Klier, Im Dreieck von Demokratie, Öffentlichkeit und Massenmedien. Dunker \& Humblot, 1990; Peter U. Hohendahl \& Marc Silbermann, "Critical Theory, public sphere and culture. Jürgen Habermas and his critics”, in New German Critique, n. 16, 1979, p. 89-118. On the relation between political public sphere and mass media in the 
Differently, I would like to show that it is not an investigative lack, but a secondary investigation. It is not necessarily absence, abandonment or exploration of the theme, but its secondary character, less significant. Although the critic comments can be a good starting point for questioning the theme, I would like to show that the argument of an investigative lack can not be sustained in the sense of absence or abandonment of the subject, but only in a secondary sense, in approaching the subject in a parallel way, implicitly. It is not true that the theme of mass media and their influence in the public sphere have not been addressed. A closer look can show that Habermas' attention to the influence of mass media after Strukturwandel der Öffentlichkeit (1962) has not been completely abandoned (which would justify the thesis of "investigative lack"). Yes, it is thematized, albeit in a secondary way, in his major works such as Theorie des kommunikativen Handelns (1981) and Faktizität und Geltung (1992), ${ }^{15}$ and in some small politics writings, as in the preface to the new edition of Strukturwandel der Öffentlichkeit $(1990)^{16}$ and in "Political communication in media society" (2006). ${ }^{17}$ Despite the

contemporary Brazil, see: Rousiley Maia \& Maria Castro, Mídia, esfera pública e identidades coletivas. Ed. UFMG, 2006; Wilson Gomes \& Rousiley Maia, Comunicação e democracia. Paulus, 2008; Wilson Gomes, "Esfera pública e media: com Habermas, contra Habermas”, in Rubin; Bentz; Pinto (Orgs.) Produção e recepção dos sentidos midiáticos. Petrópolis: Vozes, 1998.

${ }^{15}$ Habermas, Faktizität und Geltung, p. 455.

${ }^{16}$ Here Habermas returns one of the causes of public sphere decline and depoliticization, as formulated in Strukturwandel der Öffentlichkeit, namely, the influence and manipulation of the mass media (the other was a public sphere infiltrated by the state interference power) and remained implicit in the Theorie des kommunikativen Handelns (1981).

${ }^{17}$ Habermas, "Political communication in media society. Does democracy still enjoy an epistemic dimension? The impact of normative theory on empirical research". This is the title of Habermas' communication in the $56^{a}$ International Communication Association Annual Convention, June 20, 2006, in Dresden/Germany, and posteriorly published as paper in Communication Theory, 16/4, 2006, p. 411-26 (version to be used here). The version published in germany 
reformulations in the preface to Strukturwandel der Öffentlichkeit (1990), this 2006 article is the most complete and currently systematization of the theme - public sphere-mass media - since the work about public sphere of 1962. This article comes to supply the lack of a more systematic approach on two fundamental aspects that are correlated: mass media and their influence in the process of public communication. By thematizing the Power of mass media and their new dynamics of mass communication, Habermas seeks to supply its own deficit on the real potentials for democratization of a public sphere influenced and controlled by mass media.

Moreover, I suspect that the secondary aspect of Habermasian approach is related to the skeptical and pessimistic position about the negative influence of mass media in the depoliticization of the public sphere and its ambivalent democratic potential (of repoliticization), and that this position maintains an internal connection with the original position of Adorno's critique of mass culture. I suspect that the secondary argumentation of the relation public sphere-mass media, especially in the elaboration on the Habermasian political philosophy, is related with the skepticism, although implicit, in relation to the democratic potential of mass media. This means that Habermasian original understanding of the role of mass media and its influence in the public sphere seem not to have changed in its foundations and, therefore, continue Habermas' pessimism about the democratization potential of the public sphere by mass media.

The paper is divided in three parts. Firstly, I would like to show the principal moments in which the relation public sphere-mass media is thematized within the Habermasian literature, since Strukturwandel der Öffentlichkeit (1962), going through Theorie des

- "Hat die Demokratie noch eine epistemische Dimension? Empirische Forschung und normative Theorie”, in Ach Europa. Suhrkamp, 2008, cap. 10, p.138-191 have small modifications compared to the original, as the deletion of the first part of the original title, adding two explanatory graphics and the addition of two chapters, plus a Postskriptum. 
kommunikativen Handelns (1981), the reformulations in Strukturwandel der Öffentlichkeit (1990), until Faktizität und Geltung (1992) (I). Next, I would like to show how Habermas retakes this relation public sphere - mass media in "Political communication in media society" (2006), and discusses the growing increase of mass media and its role in contemporary processes of social and political interaction (II). Finally, I would like to show that, despite the resumption and reformulations about the theme and the critical discourses, Habermas' original position about the democratic potential of mass media in repoliticizing the public sphere has not changed in their foundations in these 50 years (III).

\section{I.}

\subsection{Strukturwandel der Öffentlichkeit (1962).}

The Habermasian discussion about public sphere begins in Strukturwandel der Öffentlichkeit. ${ }^{18}$ Habermas' intention is to derive a model of public sphere ("ideal type") from historical developments of the emergence of a bourgeois public sphere, informed and politized, specially in the European eighteenth and nineteenth centuries (with emphasis on England, France and Germany), and its transformation, progressive decline and disappearance of the conditions that fed the public sphere, in the twentieth century. In this trajectory, public sphere has emerged as a space for discussion and exercise of critique, independent of (or which does not follows purely the) logic of market and State, and was able to impulse, from their politic effectiveness, the necessary developments for the democratization of the pre-bourgeois forms of domination, rationalizing the power linking the dissolution of domination to the vision of a "publicity", based on critical and rational discourse.

18 Habermas, Strukturwandel der Öffentlichkeit. Luchterhand, 1962 (New Edition, Suhrkamp, 1990). 
Habermas was interested in the normative aspects (general interest, universal and rational laws or rules), as well as in the criticism of the liberal model of public sphere, which could not be able to keep the promises of power rationalization and domination neutralization. The public sphere dominated by mass media and infiltrated by power becomes a scenario of manipulation and search of legitimacy. The public sphere, which emerges as a public space of discussion and exercise of critique is redirected to the "publicity" (in the sense of Publizität as "propaganda"), and is combined with manipulative purposes.

To explain this ambivalent potential of the public sphere, capable of carrying both critical and manipulative potential, Habermas introduces the distinction between the "critical" and "manipulative" functions in the public sphere, to distinguish between genuine cases of public communication and those that have been subverted by the power. This intention provides a "provisional model", as outlined in the book of the public sphere. The "critical model", formulated from the normative features of a politized public sphere, when applied to the reality of the advanced capitalist societies, cannot be a plausible standard to measure legitimacy. This diagnostic of a public sphere depoliticized, atrophied, shrunken, presents the problem of effective implementation of the critical principle of the public sphere, whose institutional base is "corrupted". Therefore, Habermas' attempt (which follows from here) to recover a critical-normative potential or find a way of its bases remain "opened" because there is not a critical public sphere anymore. $^{19}$

19 See: Lubenow, A subversão do princípio da publicidade em Habermas. Monografia. UNIJUÍ, 1999. [The subversion of the publicity principle in Jürgen Habermas] The question that remains open here is to identify strategies of advanced capitalist societies to preserve, under present conditions, the public sphere principle (critical publicity), but not with the bourgeois forms. 
1.1.1 Structure and function of the public sphere in Strukturwandel der Öffentlichkeit

The category bourgeois public sphere refers to a political public sphere, which has configured its objective existence from a literary public sphere, the establishment of a modern literary Publikums which was constituted around conversations about literature and art. The configuration of a literary public sphere, from its institutions or centers of literary criticism such as cafes, salons and literary associations, characterized a cultural antithesis - and later politics - to the aristocratic society. It was characterized as critical sphere. The institutionalization of critical criticism through newspapers favored the publicity of part of this initially cultural critique. The newspapers were the publicity instruments that enabled the publicity of this critique of literary and cultural argumentation. The conscience that the political public sphere has of itself is mediated by institutional conscience of the literary sphere. This instance serves as a mediator for the realization of that. The political public sphere, which comes from the literary, mediates through public opinion, the state and the society's needs. The public sphere assumes explicitly political functions in the tensional field between state and society. Its function objective is essentially a sphere of mediation of bourgeois society with the state power. His political task is the regulation of the civil society to address the authority of established government, turning against the power concentration that should be shared. The public sphere attacks the principle of prevailing domination, pitting the state secret practice against the principle of publicity, confronting, thereby the political efficacy, established authority. This presupposition - the requirement of publicity - reveals a "critical sphere" which appears as public opinion.

1.1.2 Structural and functional transformation of the public sphere 
After the category of public sphere being configured, the important argumentative movement now is to analyze the condition for its exercise in advanced institutional conditions - central topic of the second half of the book Strukturwandel der Öffentlichkeit. To this end, Habermas transfers the idea of public sphere, captured from socio-historical cut, and uses it as a reading-key to analyze the decline of the public sphere: the main lines of the decadence, the subversion of the critical principle and the commitment of the democratic and emancipatory potential of the public sphere in advanced capitalist societies of the twentieth century, institutionally organized in the welfare-states form. The public sphere, space where discussions take place for the public opinion formation (critical sense), change and, thus, gains a new connotation (manipulative sense).

Two major factors are diagnosed by Habermas as responsible for transformation and subversion of public sphere: the progressive interpenetration between the public and private sector; and the expansion of the public in the public sphere and the consequent irruption of the masses in politics. For our purposes here, it is important to explore this second argument.

The expansion of the public in the public sphere is caused by three factors: the expansion of the reading public (i), the expansion of political rights (ii) and the press refunctioning (iii). The topic "expansion of the public" reveals how particular and utilitarian interests, that distort the critical principle of publicity and its political function, got infiltrated in the expanded public sphere. According to Habermas:

With the expansion of public, interests arrange their representation in a fragmented public opinion and make from the public opinion, in the configuration of a dominant opinion, a coercive 
power $[\ldots]^{20}$ It penetrates even more extensive spheres of society and, at the same time, it loses its political function, that is, submitting the facts turned publics, to the control of a critical public [...] The public sphere seems to lose the force of its principle, critical publicity, as it is expanded as a sphere $[\ldots]^{21}$

(i) The "expansion of the readers" expresses the progressive decline of that literary public sphere, decadence that can be summarized in this phenomenon: it gets closed to the resonance field of a cultured public created to use publicly the reason. ${ }^{22}$ The contexts of a minority of experts, on the one hand, and a mass of consumer influenced by public mass communication, on the other hand, express the public thinker of culture to a simply public consumer of culture, in which, it itself, the general public, is no more, as in the beginning, the subject. In this passage, the publicity loses its specific character of the principle (critical) and the public sphere now assumes functions of propaganda. ${ }^{23}$ About the inversion of the original relation of the literary public sphere, Habermas writes:

Originally, publicity guaranteed correlation with the public thought through legislative grounds of domination as well as its supervision on critical exercise. Meantime it enables the peculiar ambivalence of a domination of public opinion: it serves to the manipulation of the public as to the legitimization before him. ${ }^{24}$

\footnotetext{
${ }^{20}$ Habermas, Strukturwandel der Öffentlichkeit, p. 213.

${ }^{21}$ Habermas, Strukturwandel der Öffentlichkeit, pp. 223-24.

${ }^{22}$ Habermas, Strukturwandel der Öffentlichkeit, pp. 265-66.

${ }^{23}$ Habermas, Strukturwandel der Öffentlichkeit, p. 267.

${ }^{24}$ Habermas, Strukturwandel der Öffentlichkeit, p. 270.
} 
(ii) The "expansion of political rights", through electoral participation - the theme of electoral justice reform in the nineteenth century - was another important aspect that caused the enlargement of the public in the public sphere. Because not all are bourgeois, the tensional field between bourgeois and non-proprietors narrowed. They claim to participate in the public sphere in order to become also subjects of the public sphere. Thus, as it moves towards to become subjects of the public sphere, its structure would have to change from its base. However, the expansion of rights of political equality for all classes occurred within this same class society. That is, the expanded public sphere has not led primarily to the overcoming of that on which the public of private individuals had initially tensioned something like a "sovereignty of public opinion". This public sphere "enlargement" had a double effect: positive, with the progressive expansion of the public sphere, the enlargement of the spectrum of citizen participation in the public life; negative, because the expansion was induced in manipulate way by means of mass communication. The goal of public relations - the need to think and evaluate quickly about the opinion formulation and circulation (information) - is engendering consensus among consumers of mass culture. And this affects the formation of opinion and public consensus, rational and critical, hindering the critical and democratic functions of the public sphere.

(iii) Finally, "the commercial refunctionalisation of press". The press needs to arrange access of the mass to the public sphere. So, instead of authentic literary public sphere, it arises the sector apparently private of cultural consumption. The press, from a moment of simple information, has evolved into one press of opinion, from literary journalism. However, as it evolves to a capitalist enterprise, the press falls within the field of interests that seek to influence it. The infrastructure of the public sphere has changed with the emergence of mass media, with new forms of organization, marketing and consumption of a specialized literary production and with the press. With the growing demand for capital 
and organizational scale, the channels of communication began to have a new type of influence: the mass media power was used for private purposes of manipulation. Therefore, the press becomes manipulated as it is commercialized. Thus, the basis of the original bases of journalism institutions is exactly inverted: "While, previously, the press could only mediate and reinforce the reasoning of private people congregate in a public, this, on the contrary, turns to be now outlined by mass media". ${ }^{25}$ As these journalistic institutions begin to concentrate on economic and technical aspects, they get crystallized in complexes with high social power. The publicity industry appropriates the existing publicity agencies. Thus, the publicity, besides the influence on consumer's decision, also operates as political pressure. The publicity techniques, to the level of political action, become a key phenomenon for the diagnosis of the political sector sphere. The central task of the new shift of publicity is engendering the consensus. In Habermas' words:

"Working the public opinion" [...] also expresses commercial intentions that the emitter hides under the role of someone interested in the common good. The manipulation of consumers lends its connotations to the classic figure of a cult public of private persons and takes advantage of its legitimacy [...]. ${ }^{26}$ The availability awakened on consumers is mediated by the false consciousness that they, as private persons who think, contribute responsibly in forming public opinion. ${ }^{27}$

\footnotetext{
${ }^{25}$ Habermas, Strukturwandel der Öffentlichkeit, p. 284.

${ }^{26}$ Habermas, Strukturwandel der Öffentlichkeit, pp. 289-90.

${ }^{27}$ Habermas, Strukturwandel der Öffentlichkeit, p. 291. My italics.
} 
However, this produced consensus has not much more in common with the public opinion, with the final agreement after a laborious process of reciprocal Aufklärung. The "general interest" disappeared as private interests adopted it for themselves, in order to represent themselves through publicity. The competent critique in relation to questions politically discussed give place to a conformist behavior. If, once, publicity signified "the demystification of political dominion before the tribunal of reason use", now, on the contrary, it "subsumes the reactions of an uncompromising assent". ${ }^{28}$ Instead of developing critique, public opinion is being organized with manipulative purposes, a pre-fabricated publicity and nonpublic opinion. Thus, publicity rotates its principle against itself, reducing its critical effectiveness. According to Habermas:

In the past, the "publicity" had to be imposed against the politics of secrecy practiced by monarchs: that 'publicity' tried to submit the person or the question at public judgment and turned the decisions subject to review before the instance of public opinion. Today, on the contrary, publicity is imposed with the help of a secret policy of interest [...] The public sphere "there is" no more, it must be "produced". 29

These passages show how the public sphere becomes defined in the face of that manipulation that seeks to coadunate the provisions and the results of the continuous process of opinion formation and decision making processes. This is the synthesis of the main lines of the bourgeois public sphere decadence: the public sphere, spoiled of its original concept, draws a framework of a

\footnotetext{
${ }^{28}$ Habermas, Strukturwandel der Öffentlichkeit, p. 292.

${ }^{29}$ Habermas, Strukturwandel der Öffentlichkeit, pp. 299-300. My italics.
} 
degraded political life, in which the political content of the liberal model of public opinion was subverted in a generalized manipulation; in which public opinion has ceased to be measured as standard of legitimacy, to be dissolved into an aggregate of surveyed individual opinions, only representative in the statistical sense. What is configured in the manipulated public sphere is just an "opinion atmosphere", in general, manipulated mostly by the calculation of socio-psychological tendencies which, however, provoke expected reactions. In this sense, public opinion that results of opinion pulls is rather as coercion to conformity than a critical force. Public opinion appears simply as a uniform mass reaction:

What, according to the belief of the contemporaries, was a hundred years ago, a coercive principle of individuals in society (public opinion), has become, through time, a common place by which the pretext to escape the own efforts of mental elaboration is presented to the accommodated and spiritually indolent multitude. ${ }^{30}$

\subsection{Theorie des kommunikativen Handelns, v.2 (1981).}

Which place does the public sphere occupy, what role does it play and what is its relation with the mass media when incorporated into Theorie des kommunikativen Handelns? ${ }^{31}$

30 In: Habermas, Strukturwandel der Öffentlichkeit, pp. 347-48. On the depoliticization of the public sphere, see: Lubenow, "A despolitização da esfera pública em Jürgen Habermas”, in Garcia; Fraga; Cossetin (Orgs.), Linguagem, intersubjetividade e ação, Editora UNIJUÍ, 2003, p. 273.

${ }^{31}$ See: Lubenow, "A reorientação da categoria esfera pública na Teoria do agir comunicativo de Jürgen Habermas”, in Revista Ideação, n. 14, 2005, p. 37-59. 
Habermas takes up the themes of public sphere and mass media in the second volume of Theorie des kommunikativen Handelns, while discussing the distinction between system and lifeworld, and in which he presents his "diagnosis of time". This retake occurs, however, in the dual conception of society as system and lifeworld, and the relation between the two levels. The dual concept of society refers to the relation of two worlds structurally different by rationalization in "system" and "lifeworld". These two concepts are used by Habermas to understand the modern rationalized society; reflecting the dual concept of rationalization that ends in two types of action: instrumental and communicative; designate the functions of social integration (systemic and social) in different contexts of action (instrumental and communicative). The lifeworld is the background of communicative action, the reference horizon in which communicative agents always move, the context of linguistic communication which allows the condition of possibility of understanding and consensus. The system, in turn, integrates various activities through the regulation on unintended consequences; it refers to the ability to manipulate the formal rules; it is restricted to maintain the operation, the integration between the constitutive elements. It is in this systemic sphere that instrumental reason acts. The systemic integration is not viewed as an intentional relation between actors, but as a network of functional mechanisms that regulate the unintended consequences of these actors. This "automatic regulation" Habermas designed as "systemic integration". These mechanisms end up destroying, with its complexity, the forms of solidarity, without generating, at the same time, normative guidelines that would ensure social solidarity. The actions that are coordinated by non-linguistic means make the normative framework of the interactions go down. The lifeworld, governed by communicative reason, ends up threatened by this systemic view, which disables the spheres governed by communicative reason. This

[The reorientation of the public sphere in Theory of communicative action of Jürgen Habermas] 
"overlap” (Übergewicht) from system into lifeworld is called by Habermas as "lifeworld colonization": the manipulation of media resources by systemic imperatives "money" (economic) and "power" (administrative) and "right" (juridification), to the colonizing advance of the non-communicative systems that suppress and annihilate the lifeworld contexts capable of communication. The colonization reverts in pathologies of the lifeworld induced systemically, fragmenting it; pathologies that can suspend or suppress the capacity of communicative action. This strategy of interpretation - that the Western social modernization has developed a potential rational "one-sided" (einseitige) causing “distortions” (the colonization of the lifeworld) - allows Habermas to expose the causes of the new intransparency as well as formulate his critical perspective. $^{32}$ The lifeworld fragmentation allows Habermas to understand the constitutive anomalies of the public sphere and its concept of crisis for contemporary society.

In the interpretation in terms of the theory of communicative action, the category of public sphere is retaked in another reference framework. In the first passage, Habermas re-establishes the link with Strukturwandel der Öffentlichkeit, linking the categories of civil society and lifeworld. ${ }^{33}$ In a second passage, by the relational link between system and lifeworld, public has functions now to protect and guarantee the autonomy of lifeworld against systemic imperatives as well as the symbolic function of social integration: the solidarity that emerges from cooperation. The public sphere is the social space of communicative practice which provides vitality to the lifeworld, of the symbolic reproduction of the lifeworld, because the system cannot fulfill this role. The public sphere, thus, assumes the symbolic function of social integration, assuring the autonomy of the lifeworld before the administered system. It appears as a "conflict

\footnotetext{
${ }^{32}$ Habermas, Theorie des kommunikativen Handelns, v.2, cap. 8.

${ }^{33}$ Habermas, Theorie des kommunikativen Handelns, v.2, p. 485.
} 
zone" in which opposing principles of social integration conflict. ${ }^{34}$ Now, the public sphere has that other function, although "more defensive", to guarantee the autonomy of the lifeworld before the administered system. Differently from Strukturwandel der Öffentlichkeit, the public sphere has now a mediating position between system and lifeworld, in which its implicit normativity is realized in a process of "besiege" of the system by the lifeworld, but without pretensions of conquest. It remains the important intermediary structure that mediates the political and administrative system, and the lifeworld and civil society. However, it is interesting to note that the "communicative model" of public sphere that results from the theoretical framework of communicative action has a limited capacity of realization of a discursive social practice in institutional contexts. ${ }^{35}$ One major cause, cited by Habermas, is the role played by mass media. In the mediation between system and lifeworld, the mass media are instruments of "colonization" of the lifeworld, impeding the emancipatory potential. In this interference in the public sphere and in the lifeworld, the mass media hierarchize the horizon of possible communications, establish obstacles and substitute the structures of communication that had enabled the public discussion:

By channeling unilaterally the communication flows in a centralized network, from center to the periphery, from above to bottom, the mass media

${ }^{34}$ Habermas, Theorie des kommunikativen Handelns, v.2, pp. 507-8.

35 Habermas recognize that in the Preface to the $3^{\text {a }}$ edition of Theorie des kommunikativen Handelns, 1985. Here, Habermas accepts the criticism directed by J. Berger and already recognizes that the relation of systemlifeworld must be also reflux, double hand. On the recognition of the "defeatism" of the conception of politics and of the coupled model that resulted from the work on communicative action, see: Habermas, "Ein Gespräch über Fragen der politischen Theorie”, in Die Normalität einer Berliner Republik, p.139. 
can substantially reinforce considerably the efficacy of social controls. But the use of this authoritarian potential results always precarious, since the property structures of communication carries the counterweight of an emancipatory potential $\left[\ldots .\right.$. . $^{36}$

The logic of communicative practice puts itself on the defensive against the interventions directly manipulative of the mass media. ${ }^{37}$

As we saw, in the Theorie des kommunikativen Handelns, Habermas maintains the negative diagnosis of the manipulative role of the media in colonizing the public sphere, annulling its emancipatory potential.

\subsection{Strukturwandel der Öffentlichkeit, Vorwort zur Neuauflage (1990).}

In the new edition of Strukturwandel der Öffentlichkeit, published in 1990, ${ }^{38}$ Habermas adds a preface in which he retakes one of the causes of the decline and depoliticization of the public sphere, as formulated in Strukturwandel der Öffentlichkeit, namely, the influence and manipulation of mass media.

For Habermas, the further reflections on the genesis of the category of public sphere, in the preface to the new edition of

\footnotetext{
${ }^{36}$ Habermas, Theorie des kommunikativen Handelns, vol 2, p.573.

${ }^{37}$ Habermas, Theorie des kommunikativen Handelns, vol 2, p.574 . My italics.

38 Habermas, Strukturwandel der Öffentlichkeit, "Vorwort zur Neuauflage", Suhrkamp, 1990.

39 See: Lubenow, “A categoria de esfera pública em Jürgen Habermas: para a reconstrução da autocrítica”, in Cadernos de ética e filosofia política (USP), n. 10, v. 1, 2007, p. 103-123 [The category of public sphere in Jürgen Habermas: to a reconstruction of the selfcritique].
} 
Strukturwandel der Öffentlichkeit, aim to recognize the limitations of Habermasian description of public sphere inspired in eighteenth and nineteenth centuries, the inadequacy of its interpretation, the many restrictions of a public sphere model idealized, some deficiencies in its interpretation, relativizing some passages, justifying some interpretations "too simplistic", making some reservations about the empirical deficiencies, admitting the relevance and responding to critical discourses. ${ }^{40}$ This means the reformulation of the contents of the own category of public sphere and a reformulation of the position that the category occupies in the broader framework of the theory of communicative action and the conception of society as system and lifeworld.

The central question that had remained open since Strukturwandel der Öffentlichkeit (1962) and Theorie des kommunikativen Handelns (1981), concerned the possibility of repoliticization of a public sphere not manipulated by mass media and not subverted by the power. Now, this question would be retaken and connected to the theme of "civil society". The configuration of a new public sphere is thematized and discussed, especially by social theory in the 90's, under the rubric of "rediscovery of civil society" (zivilgeselschaftliche Ausbruch). ${ }^{41}$ Resulting from a new political dynamic, with an advancement of civil society over the state, the growth of civil society organizations indicates the strengthening of a public sphere relatively autonomous from the state. This new political dynamic, with new democratic experiences, promoted a fertile ground for rethinking categories and renewing discussions on topics such as participation, democracy, civil society, citizen

${ }^{40}$ Habermas, new preface to Strukturwandel der Öffentlichkeit, 1990. About critical discourses, see the contributions edited by Craig Calhoun, Habermas and the public sphere. MIT Press, 1992, this book was organized in honor of the English translation of the new edition of Strukturwandel der Öffentlichkeit in USA in 1990 (English translation: The structural transformation of the public sphere); Cohen \&Arato, Civil society and political theory, MIT Press, 1992.

${ }^{41}$ Habermas, Strukturwandel der Öffentlichkeit, "Vorwort zur Neuauflage”, p. 45. 
autonomy, civil rights, human rights, social justice, institutionalism, among others. Now, the concept of civil society does not already refer to what identified the bourgeois society as civil society in general. The new current meaning of civil society refers to informal associations which form opinion and will, such as cultural associations, reading and discussion, churches, alternative institutions, among others. Autonomous public spheres, which are not part of the political-administrative system, but that articulate and organize political influence by public means of communication, participation and deliberation, contributing to, thus, thematization, public discussion and decision making.

The concept of civil society came to light, especially, with the emergence of dissident forces of the socialist states of Eastern Europe. Social movements have mobilized changes around demands of civil liberties and democratic politics - something that was already assured, at least formally (formal equality), in Western societies against the totalitarian annihilation of political public sphere and the inhibition of the emergence of autonomous public spheres, selfopinion-forming associations, which were under control of the apparatus of domination. The concept of civil society acquires a more positive connotation.

Therefore, the question that arises is: what is the chance of civil society putting the issues and determining the direction of communication flows, which could culminate in formal treatment of new and politically relevant themes? With a public sphere dominated by mass media and infiltrated by power, how can members of civil society have the chance of channeling influence and promoting changes?

For Habermas, these questions cannot be answered without considerable empirical research, since there is strong evidence attesting to the ambivalent potential of a democratic public sphere whose infrastructure is characterized by gradual, selective and 
constraining influence imposed by electronic mass media. ${ }^{42}$ However, Habermas would be occupied with empirical research only later in "Concluding comments on empirical approaches to deliberative politics" (2005) and in "Political communication in media society" (2006). At that moment, Habermas was interested in the reformulations about his theory of public sphere formulated in the 60's. Despite this, it is worth noting in this review that Habermas reaffirms the pessimism in relation to power of resistance and the critical potential of a public dominated by mass media that could undermine the class structures. ${ }^{43}$ In another passage Habermas justifies:

The theoretical problems are different now than they were in the late 50's and in the beginning of the 60's when this study appeared [...] The contemporary scene has changed, i.e., the extrascientific context that forms the horizon of experience which social research derives its perspective. My own theory has, finally, also changed, although, less in its foundations than in its degree of complexity. ${ }^{44}$

\subsection{Faktizität und Geltung (1992)}

In Faktizität und Geltung, Habermas reformulates the relation system-lifeworld and changes the characteristics of public sphere, re-

\footnotetext{
${ }^{42}$ Cf. Habermas, Strukturwandel der Öffentlichkeit, "Vorwort zur Neuauflage”, p.47.

${ }^{43}$ Habermas, Strukturwandel der Öffentlichkeit,"Vorwort zur Neuauflage”, p. 27.

${ }^{44}$ Habermas, Strukturwandel der Öffentlichkeit, "Vorwort zur Neuauflage”, p.12. My Italics.
} 
dimensioning it within a system of "sluices". ${ }^{45}$ In Theorie des kommunikativen Handelns, Habermas thematized the public sphere as constitutive of the lifeworld, responsible for ensuring its autonomy and protecting it against the administered system. A sphere of "defense" character that, at most, would "besiege" the system, but without great conquest pretensions. Already in Faktizität und Geltung, Habermas gives to the public sphere a more "offensive" character, abandons the metaphor of "besiege" and replaces it by adopting the model of "sluices". It means the abandonment of the theory of decoupling between system and lifeworld and the formulation of a different conception of power and political system in Faktizität und Geltung. ${ }^{46}$

In the offensive counterpart of the new circulation model of political power, communication processes and decision of political system are structured by a system of sluices, in which communication processes and decision are already anchored in the lifeworld by a "structural opening", permitted by a sensitive, permeable public sphere, able to introduce into the political system existing conflicts at the periphery. For Habermas, this unleashing is bound to a process of normalization, which begins with the formation of opinion and will in the informal public sphere and ends flowing, along procedural way, in formal instances for deliberation and decision. This process of "opening" to institutionalization is

45 See: Lubenow, "Esfera pública em Habermas: da 'Teoria da ação comunicativa' (1981) à 'Direito e democracia' (1992)”, in Revista Ideação, n.18, 2007, p. 79122. [Public sphere in Jürgen Habermas: from 'Theory of communicative action' to 'Facts and norms'].

${ }^{46}$ Habermas, Faktizität und Geltung, p. 430; Lubenow \& Neves, "Entre promessas e desenganos: lutas sociais, esfera pública e direito", in Nobre \& Terra, Direito e democracia: um guia de leitura. São Paulo: Malheiros, 2008, p. 249. [Between promises and disappointments: social struggles, public sphere and right]. 
anchored on a broad concept of procedural and deliberative democracy. ${ }^{47}$

In the Habermasian terms, the procedure of deliberative politics is the heart of the democratic process. ${ }^{48}$ The public sphere, in turn, is the normative key category of the Habermasian deliberative political process. The public sphere is an "intermediate structure" that makes the mediation between state and political system, and the private sectors of the lifeworld. ${ }^{49}$ A "communicative structure", a potential center of public communication, that reveals a reasoning of public nature of opinion formation and political will, rooted in the lifeworld through civil society. The public sphere is related with the "social space" from which a discursive formation of opinion and political will can emerge. In its nucleus, conflicts collide about the control of communicative flows that cross the limit between lifeworld and civil society, and political and administrative system. The public sphere constitutes a "resonance box", ${ }^{0}$ provided with a sensors system sensitive to the context of the society as a whole, ${ }^{51}$ and it has the function to filter and synthesize themes, arguments and contributions; transport them to the level of institutionalized processes of resolution and decision; and, introduce into the political system existing conflicts in civil society, in order to influence and direct the processes regulation and circulation of power in the

${ }^{47}$ Cf. Habermas, Faktizität und Geltung, cap. 7; Lubenow, "Esfera pública e democracia deliberativa em Habermas: modelo teórico e discursos críticos", em Revista Kriterion (UFMG), n. 121, 2010, p. 227-258 [translation: "Public sphere and deliberative democracy in Jürgen Habermas: theoretical model and critical discourses”, in American Journal of Sociological Research, v.2, n.4, 2012].

${ }^{48}$ Habermas, Faktizität und Geltung, p. 359.

${ }^{49}$ Habermas, Faktizität und Geltung, p. 451.

${ }^{50}$ Habermas, Faktizität und Geltung, p. 400; 417.

${ }^{51}$ Habermas, Faktizität und Geltung, p. 364. 
political system, ${ }^{52}$ through a structural opening, sensitive and porous, anchored in the lifeworld. ${ }^{53}$

Furthermore, public sphere has as elementary characteristic being an unrestricted space of communication and public deliberation, which cannot be previously established, limited or restricted; the constituent elements cannot be anticipated. In principle, it is open to all social ambits. There are no themes or contributions incorporated or excluded a priori. Public sphere is always indeterminate regarding the contents of political agenda and to individuals and groups that can appear in it. That is why Habermas does not want (or can) describe precisely internal and external lines and the borders of public sphere, although it needs, on the other hand, a certain self-limitation, for example, for not getting exposed to all or any form of public manifestation (such as strategic forms of communication). This is the constitutive dual character of public sphere, by which it ends oscillating between the need for participation and free movement of themes and contributions, and a certain self-limitation. ${ }^{54}$ To this end, Habermas proposes adopting the procedural idea of public deliberation, by which the "contours" of public sphere are forged during the processes of identification, filtering and interpretation about emerging themes and contributions of autonomous public spheres and are conducted to formal and institutionalized forums of the political and administrative system. ${ }^{55}$

${ }^{52}$ Habermas, Faktizität und Geltung, pp. 364; 398; 435; 532-33.

${ }^{53}$ Habermas, Faktizität und Geltung, pp. 429-30; 435-36; 452.

${ }^{54}$ About this dual politics, see: Cohen \& Arato, Civil society and political theory, 1992, p. 460; Demirovic, "Hegemonie und Öffentlichkeit”, in Das Argument, n. 4-5, 1994, p. 689.

55 Thus, Habermas wants to solve a problem that has also appeared on the seminal work of the public sphere in 1962. The power of civil society can not be associated with the idea of a particular people that has in the state its institutional embodiment (the counterpart institution of civil society) - a direct influence on institutional design which characterizes a republican popular sovereignty (as happened in the work of 1962) This influence must be mediated, to proceed through "means", to be "proceduralized". On this, see: 
It is in this procedural character of justification of the legitimacy that the normativity of public sphere is realized. ${ }^{56}$ It is from the interrelation between public informal and formal public sphere - that is, the communicative flows and public influences that emerge from the informal public spheres, autonomous, and are transformed into communicative power and transported to the formal sphere - that the normative expectation of public sphere derives. ${ }^{57}$

However, according to the critical discourses, despite the offensive counterpart, the impulses coming from civil society, and which pass through public sphere, provide a very limited scope for action for the non-institutionalized forms of political expression; the "mechanisms of transformation" would not be very clear; the existence of a "structural deficit" of the deliberative public sphere: a loosening of the informal process of lifeworld and civil society of the formal instances of decision making, which makes claims and alternative actions, i.e., a critical practice, to remain restricted and limited. $^{58}$

Leonardo Avritzer, Além da dicotomia estado/mercado: Habermas, Cohen e Arato, in Novos Estudos CEBRAP, n. 36, 1993.

${ }^{56}$ Regh \& Bohman, "Discourse and Democracy: the formal and informal bases of legitimacy in 'Between facts and Norms'”, in Schomberg \& Baynes, Discourse and democracy, 2002, pp. 31-60.

${ }^{57}$ Habermas, Faktizität und Geltung, “Nachwort”, p. 625.

58 About critical discourses, see: Neidhardt, Öffentlichkeit, öffentliche Meinung, soziale Bewegung, p. 32-34; B. Peters, "Der Sinn der Öffentlichkeit”, p. 48-9; Peters, "Deliberative Öffentlichkeit”, p. 657; Kenneth Baynes, "Democracy and the Rechtsstaat: Habermas's 'Faktizität und Geltung'”, in White, The Cambridge Companion to Habermas, p. 216; John Sitton, "The limitations of Habermas's social and political argument”, in _. Habermas and the contemporary society, p. 121-140; James Bohman, "Pluralismus, Kulturspezifizität und kosmopolitische Öffentlichkeit im Zeichen der Globalisierung”, in Deutsche Zeitschrift für Philosophie 45.6, 1997, p. 927941; Kenneth Baynes, "Deliberative democracy and public reason”, p. 35; William E. Scheuerman, "Between radicalism and resignation: democratic theory in Habermas's 'Between Facts and Norms'”, in Peter Dews, Habermas: a Critical Reader, Oxford: Blackwell, 1999, p. 153-177; Nancy Fraser, "Rethinking the public sphere: a contribution to the critique of the actually 
It is important to emphasize that Habermas himself, for example, comes to share with Cohen and Arato a certain dose of skepticism about the possibilities offered by public sphere dominated by mass media, that the signals emitted are very weak and the impulses that are provided are generally little active and influential to awake and reorient the decision processes of political system. The proper mode to operate, of these means, in developing strategies and mechanisms of communication affects the public sphere, reducing the level of discourse of the public circulation of communication, depoliticizing it. This preoccupation of Habermas increases even more their skepticism about the chances of civil society to exert influence on political system. ${ }^{59}$

In Volume II, Chapter 7, "The role of civil society and the political public sphere", we find many references about the influence of mass media in the depoliticization of public sphere. ${ }^{60}$ When describing the barriers and structures that arise within the public sphere, and the chances of civil society to influence the

existing democracy”, in Calhoun, Habermas and the public sphere. Cambridge: MIT Press; Wingert \& Günther, Die Öffentlichkeit der Vernunft und die Vernunft der Öffentlichkeit. Suhrkamp, 2001; Crossely \& Roberst, After Habermas: new perspectives on the public sphere. Blackwell, 2004; W. Daele \& F. Neidhardt, Kommunikation und Entscheidung. Politische Funktionen öffentlicher Meinungsbildung und diskursiver Verfahren. Berlin: Sigma, 1996. See also: Lubenow, "As críticas de Axel Honneth e Nancy Fraser à filosofia política de Habermas”, in Revista Veritas (PUC-RS) v. 55, n.1, 2010, 121-134. [The critics of Axel Honneth and Nancy Fraser to Habermas' political philosophy].

59 Habermas, Faktizität und Geltung, p. 449, 455-58. See also: H. Brunkhorst, "Globale Solidarität: Inklusionsprobleme der modernen Gesellschaft", in Wingert \& Günther, Die Öffentlichkeit der Vernunft und die Vernunft der Öffentlichkeit, 2001, p. 605-626; Brunkhorst, "Globalising democracy without a state: weak public, strong public, global constitutionalism”, in Millenium Journal of International Studies 31, 2002, p. 675-690; Brunkhorst, "Demokratie in derWeltgesellschaft. Hegemoniales Recht, schwache Öffentlichkeit, Menschenrechtspolitik”, in Bloch-Jahrbuch, 2003, p.147-162.

${ }^{60}$ Cf. Habermas, Faktizität und Geltung, p. 431, 444. 
parliamentary complex, forcing the political system to change the course of official power, Habermas writes: "The sociology of mass communication is skeptical about the possibilities offered by traditional public spheres of Western democracies, dominated by the power and the media". ${ }^{61}$ And, by describing the functioning of the public sphere dominated by mass media - who choose, control, centralize and are influenced by capital, Habermas affirms:

A third group is formed by reporters who collect information, decide upon the choice and presentation of "programs", controlling, somehow, the access of themes, and authors contributions to the public sphere dominated by the media [...]

The increasing complexity of the media and the increase of capital provoke a centralization of the media [...]

While the mass media [...] prefer publicity strategies that reduce the discursive level of public circulation of public communication, the themes in general will be addressed in a centrifugal direction, which goes from the center out. ${ }^{62}$

In another passage we can find a more complete description of how the structure and mode of operation of the public sphere dominated by the media imply on the source of a new sort of power: the media power. The processes of selection strategically designed by experts in publicity, the imposition of informations, the mixing of information and entertainment are the major causes of the depoliticization of public sphere:

\footnotetext{
${ }^{61}$ Habermas, Faktizität und Geltung, p. 451. My emphasis.

${ }^{62}$ Habermas, Faktizität und Geltung, p. 454, 455, 458. My italics.
} 
In general, you can say that the political image constructed by television is composed of themes and contributions that have been produced to the publicity and posted in it through conferences, information, campaigns, etc. The producers of information impose themselves in the public sphere through their professionalism, technical expertise and personal presentation. While collective actors, who operate outside the political system or outside the social organizations and associations, have usually less chances to influence the contents and positions of the major media. This is especially true for opinions that extrapolate the range of opinions of the vast electronic media, "balanced", little flexible and limited to the center. Before being put into the air, such messages are submitted to development of information strategies, which are guided by the reception conditions dictated by the experts in publicity. And once the disposition of reception, cognitive ability and attention of the public are an extremely scarce font [...] the presentation of news and comment follows advice and receipts from professionals in publicity. The personalization of objective questions, the mix between entertainment and information, the episodic developing and the fragmentation of contexts form a syndrome that promotes the depoliticization of public communication. This is the real nucleus of the culture industry theory. ${ }^{63}$

Note how this negative diagnosis of a depoliticized public sphere by the mass media maintains an internal connection to the

${ }^{63}$ Habermas, Faktizität und Geltung, p. 455-56. My italics. 
critique of culture as culture industry, the original orientation of Critical Theory, especially Adorno. The power of the media, transformed into political publicity influence, undermines the chances of civil society to overcome the barriers and influence the political system. Moreover, this negative diagnosis impedes Habermas to indicate who subject would be able to put the themes and determine the direction of communication flows or even reverse them "from the periphery to the center". As we saw, this negative diagnosis has not changed in its foundations of the Habermasian original position, because here we don't have also a "critical” but only a manipulative public sphere. Then the source of skepticism:

When we become conscious of the diffuse image of the public sphere transmitted by sociology of mass communication, which appears subjected to the power and dominated of mass media, our skepticism grows in relation to the chances of civil society exerting influence on the political system. ${ }^{64}$

Finally, although he has retaken the theme of mass media in the work on law and democracy, further, in an interview published in 1995, when answering questions about the mass media power and the need to regulate the influence of mass media in the political sphere, Habermas recognizes that this operation requires an "institutional fantasy" (institutionelle Phantasie), and that he himself did not occupy sufficiently with this. ${ }^{65}$ This means that a detailed analysis of the use of the deliberative model of public communication remained not thematized more explicitly and systematically, at least until "Political communication in media

\footnotetext{
${ }^{64}$ Habermas, Faktizität und Geltung, p. 458. My italics.

${ }^{65}$ Habermas, "Interview mit der Frankfurter Rundschau", in Die Normalität einer Berliner Republik, 1995, p. 80-81.
} 
society" (2006). Here, Habermas retakes the relationship of public sphere with mass media to thematize the growing increment of mass media and their role in contemporary processes of social and political interaction.

\section{II.}

After Faktizität und Geltung, several scholars of Habermas - as well as himself - have been occupied with the empirical implications of the deliberative model of public communication. ${ }^{66}$ From numerous researches, studies evidences of the impact of deliberative procedure on the formation of political preferences can be conferred in empirical studies with small groups, ${ }^{67}$ as well as in studies of deliberation in large-scale (public spheres and institutions at national and international levels). ${ }^{68}$ However, if the results indicate that

${ }^{66}$ For empirical researches on deliberative model, see: A. Bächtiger \& Jürg Steiner, Empirical Approaches to Deliberative Democracy, in Acta Politica, v. 40, 2005, n.2-3; M. Nobre \& V. S. Coelho, Participação e deliberação: teoria democrática e experiências institucionais no Brasil Contemporâneo. Editora 34, 2004; Lubenow, "Política deliberativa: modelo teórico e referências empíricas", in Argumentos: Revista de Filosofia, n.8, 2012, p. 199-209 [Deliberative politics: theoretical model and critical discourses].

67 About "Deliberations Among Citizens”, see: Conover \& Searing, Studying 'every political talk' in the deliberative system, in Acta Politica 40, n.3, p. 269; Fishkin \& Luskin, Experimenting with a democratic ideal: deliberative polling and public opinion, in Acta Política 40, n.3, p. 284; Nobre \& Coelho, Participação e deliberação, parte II.

${ }^{68}$ About "Deliberation in formal arenas”, see: A. Bächtiger et al, “The deliberative dimensions of legislatures", in Acta Politica 40, n.2, p. 225; K. Holzinger, "Context or conflict types: which determines the selection of communication mode", in Acta Politica 40, n.2, p. 239. About "Deliberation at the international level", see: D. della Porte, "Deliberation in movement: why and how to study deliberative and social movements", in Acta Politica 40, n.3, p. 336; C. Ulbert\& T. Risse, “Deliberative changing the discourse: what does make arguing effective?”, in Acta Politica 40, n.3, p. 351; P. Nanz\& J. Steffek, "Assessing the democratic quality of deliberation in international level: criteria and research strategies", in Acta Politica 40, n.3, p.368; e Nobre \& Coelho, Participação e deliberação, 2004, parte I. 
questions of participation and deliberation work better in local interactions, providing more effective ways of democratic participation, ${ }^{69}$ problems arise when we analyze the case of deliberative procedures in European and international arenas. ${ }^{70}$ At this level, the discussion revolves around the "democratic deficit", questions of rationality and legitimacy problems in the processes of decision making. ${ }^{71}$

Habermas himself in recent years shifted its theoretical focus from the national public sphere to the realm of normative

${ }^{69}$ Cf. Conover \& Searing, "Studying 'everyday political talk' in deliberative system”, in Acta Politica 40, n. 3, p. 269; Hayer \& Wagenaar, Deliberative policy analysis, p. 67, 95-6.

${ }^{70}$ About this, see: “Deliberation at the International Level”, in Acta Politica 40, n.3; David Held, Democracy and the global order. From the modern state to cosmopolitan governance, 1995; Bohman, "Pluralismus, Kulturspezifizität und kosmopolitische Öffentlichkeit im Zeichen der Globalisierung”, in Deutsche Zeitschrift für Philosophie 45/6, 1997, p. 927-941; Klaus Eder, "Zur Transformation nationalstaatlicher Öffentlichkeit in Europa”, in Berliner Journal für Soziologie, n.2, 2000, p. 167-184; Koopmans \& Erbe, “Towards a European public sphere? Vertical and horizontal dimensions of Europeanized political communication”, in Innovation 17.2, 2004, p. 97-118; Nanz, European Community without a demos? Rethinking conceptions of the public sphere, 2005.

${ }^{71} \mathrm{D}$. della Porta is concerned with the deliberation in transnational social movements, in particular the anti-globalization movements in Italy ("Deliberation in movement: why and how to study deliberative and social movements", in Acta Política 40, n.3, p. 336). C. Ulbert e T. Risse present some evidences about argumentation and bargaining in multilateral negotiations, persuasion processes capable of changing the Author's perception in situation and definition of the interests ("Deliberative changing the discourse: what does make arguing effective?”, in Acta Política 40, n.3, p. 351). P. Nanz e J. Steffek present a research program to analyze the "democratic quality" of deliberative procedures in international governmental level, the role of civil society actors as mediators between the processes of decision making in international organizations emerging transnationally ("Assessing the democratic quality of deliberation in international level: criteria and research strategies”, in Acta Política 40, n.3, p. 368). 
international political theory. ${ }^{72}$ However, Habermas notes that, at this level, the deliberation in public sphere, as a mechanism for problem solving and conflict resolution, is still weakly institutionalized. ${ }^{73}$ Moreover, there are obvious failures in the deliberative proceedings of a political public sphere dominated by a public communication mediated by mass media and power structures, because the dynamics of mass communication are directed by the selective power of the media and the strategic use of social and political power to influence triage and setting the agenda of public issues. ${ }^{74}$ Despite numerous analyzes of new resources and technologies that influence the media

${ }^{72}$ Cf. Habermas , Die postnationale Konstellation, 1998; Zeit der Übergange, 2001; Der gespaltene Westen, 2004; Zwischen Naturalismus und Religion, 2005; Ach Europa, 2008; Zur Verfassung Europas, 2011.

${ }^{73}$ Cf. Habermas, "Concluding comments", in Acta Politica 40, n.3, p. 386. And this is the starting point of theoretical and empirical critical studies on the deliberative procedures in the international sphere of politics, some published in the Journal Acta Politica 40. Moreover, se the contributions of: Hauke Brunkhorst, Demokratischer Experimentalismus. Politik in der komplexen Gesellschaft, 1998; Brunkhorst, Recht auf Menschenrecht. Menschenrechte, Demokratie und Internationale Politik, 1999; Brunkhorst, Globalisierung und Demokratie. Wirtschaft, Recht, Medien, 2000; Brunkhorst, "Globalising democracy without a state: weak public, strong public, global constitutionalism”, in Millenium - Journal of International Studies 31, 2002, p. 675-690; Brunkhorst, "Globale Solidarität: Inklusionsprobleme der modernen Gesellschaft", in L. Wingert (ed.) Die Öffentlichkeit der Vernunft und die Vernunft der Öffentlichkeit, 2001, p. 605-626; Brunkhorst, Solidarität. Von der Bürgerfreundschaft zur globalen Rechtsgenossenschaft, 2002; Brunkhorst, Peripherie und Zentrum in der Weltgesellschaft, 2004; Brunkhorst, Jenseits von Zentrum und Peripherie. Zur Verfassung der fragmentierten Weltgesellschaft, Rainer Hampp Verlag, 2005; Sérgio Costa, As cores de Ercília. Esfera pública, democracia, configurações pósnacionais. UFMG, 2002.

74 Cf. Habermas, "Political communication in media society", p. 414-15. For example, the absence of two crucial elements of the public communication in the Habermasian sense: the face-to-face interaction among participants in a collective decision-making, and the reflexivity between the roles of recipients in an equal exchange of claims and opinions (cf. Habermas, "Political communication in media society”, p. 415). 
in different ways, a deficit remains in the introduction of deliberative elements, for example, in electronic communication. According to Habermas: "The guided discussions in the internet, such as chatrooms, or things like that, provide a discursive unity abstract, spontaneous, isolated and weakly institutionalized, and that can be analyzed in parallel to the broad political context" ${ }^{75}$

In this sense, Habermas elaborates a communicative model of deliberative legitimacy in "Political communication in media society" (2006). This is a more appropriate analytical approach to analyze the formal and informal procedures of political public communication in contemporary Western societies, abstractly mediated by the media. With this, Habermas wants to clarify issues some of which are not elucidated by empirical approaches - on the empirical content and applicability of the deliberative model of public communication ${ }^{76}$, and "update" Habermasian reading about the growing influence of the dynamics of mass communication and its pathologies in political communication in the processes of social interaction and political context. ${ }^{77}$ In the following, I would like to present Habermasian updated understanding of the structures of mass communication, the structure of the political public sphere, the arenas of political communication and public opinion formation (2.1), the relation between the power structures of public sphere and the dynamics of mass communication (2.2), and, finally, the pathologies of the political communication (2.3). This allows elucidating the current skeptical position of Habermas about public sphere and mass media.

\subsection{Public sphere and the arenas of communication}

\footnotetext{
75 Habermas, “Concluding comments”, in Acta Política 40, n.3, p. 384. My emphasis.

${ }^{76}$ Cf. Habermas, "Political communication in media society”, chapters 1 and 2.

${ }^{77}$ Cf. Habermas, "Political communication in media society”, chapters 3, 4 and 5.
} 
In Chapter $\mathrm{III},{ }^{78}$ Habermas describes the structure of mass communication, the public opinion formation and the arenas of political communication:

Imagine the public sphere as intermediary system of communication between formally organized and informal face-to-face deliberations in arenas at both the top and the bottom of the political system [...] The center of the political system consists of the familiar institutions: parliaments, courts, administrative agencies, and government. Each branch can be described as a specialized deliberative arena. The corresponding output legislative decisions and political programs, rulings or verdicts, administrative measures and decrees, guidelines, and policies - results from different types of institutionalized deliberation and negotiation process. At the periphery of the political system, the public sphere is rooted in networks for wild flows of messages - news, reports, commentaries, talks, scenes and images, and shows and movies with an informative, polemical, educational, or entertaining content. The published opinions originate from various types of actors - politicians and political parties, lobbyists and pressure groups, or actors of civil society. They are selected and shaped by mass-media professionals and received by broad and

${ }^{78}$ In Germany edition of 2008, chapter 4, p. 163. 
overlapping audiences, camps, subcultures, and so on. $^{79}$

According to this diagnosis, mediated political communication in public arenas is exercised by an elite; besides the two types of actors that political public sphere could not work without professionals of media system and politicians - Habermas distinguishes other five types of actors who appear on the stage establishing a virtual public sphere: lobbyists, advocates, experts, moral entrepreneurs and intellectuals. Public opinions are prepared by media professionals and political elites which produce an elitist discourse which, at the same time, is powered by actors who struggle for access and influence on the media (politicians and political parties, lobbyists, advocates, interests groups, intellectuals, churches, and others). ${ }^{80}$

In contrast, the deliberation in public sphere, as an essential element of the democratic process, has as expectation completing three tasks: mobilizing and bringing together relevant issues and information required, and specifying interpretations; processing such contributions discursively through adequate arguments pros and cons; and generating attitudes rationally motivated yes and no which have the expectation of determining the result of decisions procedurally correct. In the view of the process of legitimation as a whole, the facilitating role of political public sphere is principally completing only the first of these functions and, thus, preparing the agendas of political institutions. Despite being a very demanding expectation, it is a realistic scheme of the necessary conditions for the formation of public opinion considered which can produce nonarbitrary standards for the identification of causes of communicative pathologies. ${ }^{81}$ Despite the impersonal and asymmetrical structure of

\footnotetext{
${ }^{79}$ Habermas, "Political communication in media society", p. 415-16.

${ }^{80}$ Cf. Habermas, "Political communication in media society”, p. 416.

${ }^{81}$ Cf. Habermas, "Political communication in media society”, p. 416.
} 
mass-media, that the power structure of public sphere can distort the dynamics of mass communication and interfere with normative requirements of relevant issues, regardless of the attitudes of governments and voters, the most important feature of public sphere is its reflexive character: all participants can review public opinion and reconsider them. These responses, from above and below, provide a double test of how effective political communication in public sphere can function as a filtering mechanism. ${ }^{82}$

2.2 Types of power and the dynamics of mass communication

In Chapter IV ${ }^{83}$ Habermas distinguishes four types of power political, social, economic, media - to describe the power structure of public sphere and the dynamics of mass communication. The following passages elucidate the influence of media power, the stratification, privileged access and disadvantage of civil society actors:

From the viewpoint of democratic legitimacy, media power nevertheless remains "innocent" to the extent that journalists operate within a functionally specific and self-regulating media system [...] Politicians and political parties... they hold a strong position as regards negotiation privileged access to the media. [...] They are in a position to use professional techniques to transform social power in political muscle. Its follows that compared with politicians and lobbyists, the actors of civil society are in the weakest position. [...]

\footnotetext{
${ }^{82}$ Cf. Habermas, "Political communication in media society", p. 418.

${ }^{83}$ In Germany edition of 2008, chapter 5, p. 173.
} 
Players on the virtual stage of the public sphere can be classified in terms of the power or "capital” they have at their disposal. The stratification of opportunities to transform power into public influence through the channels of mediated communication thus reveals a power structure. ${ }^{84}$

In contrast, Habermas presents two requirements that must be obtained for the game rules being correct: a self-regulating media system needs to maintain its independence with their surrounding while it links political communication in public sphere with civil society and political center; the inclusive civil society needs to encourage citizens to participate and respond in public discourse that, in turn, cannot degenerate into a mode of colonized communication. ${ }^{85}$ These two requirements will serve as critical thrust to find legitimacy faults of political communication.

\subsection{Pathologies of political communication}

In Chapter $\mathrm{V},{ }^{86}$ Habermas discusses the pathologies of political communication. According to the Frankfurter author, there are evidences that the type of political communication that is developed in societies integrated by media manifest pathologies that contrast with the normative requirements of deliberative politics. Therefore, Habermas suggests the use of a realistic scheme with necessary conditions so that the generation of public communication can produce non-arbitrary standards of public opinion, capable of identifying the causes of communicative pathologies. This empirical use of the deliberative model has a critical invested: it allows reading

\footnotetext{
${ }^{84}$ Habermas, "Political communication in media society", p. 419.

${ }^{85}$ Cf. Habermas, "Political communication in media society", p. 420.

${ }^{86}$ In Germany edition of 2008, chapter 5, p. 179.
} 
the contradictory data as indicators of contingent contradictions that need to be better investigated. ${ }^{87}$

The Habermasian communication model of democratic legitimacy focuses on two critical conditions: if the self-regulatory media system maintains its independence while linking political communication in public sphere with civil society and the political center (a), and if it guarantees the relation between the mediated and informed political communication and responsible civil society adequately (b) ${ }^{88}$ Only, thus, the political communication mediated by public sphere can facilitate deliberative legitimation processes.

(a) For Habermas, there are numerous examples of an incomplete differentiation between media system of its surroundings and temporary interference of mass media in political system. Examples of stratification of opportunities and transformation of media power in public influence (political parties, special interest groups, public interest groups, civil society actors). In this sense, Habermas cites some examples of this complex entanglement between electronic media in political system: the state monopoly which public communication enjoyed in Italy during the three decades after the Second World War; the case of public opinion manipulation by the U.S. White House before and after the invasion and war in Iraq; and the private TVs: media magnates, who first explore legal opportunities for political self-promotion, and after taking power, they use this media empire to legislate dubiously in favor of the consolidation of private fortunes and own political triumph. Habermas cites examples infamous, as Silvio Berlusconi Italian case, who had succeeded a change in media culture of Italy, shifting the emphasis from political education to market of depoliticized entertainment. ${ }^{89}$

\footnotetext{
${ }^{87}$ Cf. Habermas, "Political communication in media society”, p.420.

${ }^{88}$ Cf. Habermas, "Political communication in media society”, p. 420.

${ }^{89}$ Cf. Habermas, "Political communication in media society”, p. 420-21.
} 
(b) In the inter-relationship between the media system selfregulating and responsible civil society, there are two main causes of a systematic lack of these types of feedback: social deprivation and cultural exclusion explain the selective access and unequal participation in mediated communications (b1) and colonization of public sphere by market imperatives, redefining political in market categories causing a peculiar paralysis of civil society (b2). ${ }^{90}$

(b1) It is a sociological consensus that problems of access and participation of citizens in mediated communications are linked to social status and cultural background. This indicates an insufficient functional differentiation of political public sphere of the class structures of civil society. About the matter of inclusion of more citizens in communication flows, recent studies indicate ambivalence, if not a pessimistic conclusion about the type of impact of mass media in citizen involvement in politics. Studies indicate that people who use electronic media, and consider it an important information tool, have a low level of confidence in politics and they are more likely to take a cynical attitude to politics as a consequence. However, if confidence in radio and television stimulates feelings of powerlessness, apathy and indifference, we should not seek to explain the paralysis of civil society, but the content and format of a degenerate kind of political communication. ${ }^{91}$

(b2) The colonization of public sphere in terms of market is a consequence of the redefinition of politics in market categories. Although a process of independence of media in politics and economy, the media ended up reconnecting with the market. ${ }^{92}$ Under pressure of shareholders who are pressing for income (money), it is the intrusion of functional imperatives of the market economy in the internal logic of the production and delivery of messages that convert

\footnotetext{
${ }^{90}$ Cf. Habermas, "Political communication in media society”, p. 421-22.

${ }^{91}$ Cf. Habermas, "Political communication in media society", p. 422.

${ }^{92}$ For Koller, this would be "the second structural transformation of the public sphere" (Koller, A. The second structural transformation on the public sphere in Western Europe and the U.S., 2006, p. 19-30).
} 
the displacement from one category of communication to another: political discourse issues are assimilated and absorbed by the modes and contents of entertainment. In addition to personalization, dramatization of events, simplifying complex issues and the polarization of conflicts promote civil privatism and an anti-politics atmosphere. $^{93}$

As we saw, the use of the deliberative model to interpret empirical results can help to discover the specific causes of the existence of legitimacy deficits and the variables that explain failures in the maintenance of a media system self-regulated and an appropriate feedback between public sphere and civil society. Furthermore, using Habermas' deliberative model, a pessimistic conclusion comes up again: the depoliticization of public sphere. The colonization of public sphere in terms of the market means the displacement of the category of political and critical public sphere to a public sphere manipulated and degenerated by the entertainment strategies of mass media.

III.

As seen, the original conclusion of Strukturwandel der Öffentlichkeit (1962) - the depoliticization of public sphere remained being, although secondary, the pessimistic position of the negative effects of mass culture in public sphere that remained throughout Habermasian literature in these past 50 years. To conclude it, I would like to reinforce, from a few direct citations, how this position is related to the secondary position of Habermas

${ }^{93}$ Cf. Habermas, "Political communication in media society”, p. 25-27. According to Habermas, the growing status of the image of the candidate explains the patterns of candidate-centered electoral politics, a personalization of politics. 
about the negative effects of mass culture and how it keeps proximity to Adorno's critical theory of mass culture industry. ${ }^{94}$

In Strukturwandel der Öffentlichkeit (1962), the critique of culture industry is retaken as a depoliticization of public sphere by the manipulative influence and concentration of power and capital of mass-media. In Theorie des kommunikativen Handelns (1981), Habermas describes the manipulative role of mass media as colonization instruments of the lifeworld, obstructing the emancipatory potential of lifeworld and public sphere. From the preface to the new edition of Strukturwandel der Öffentlichkeit (1990), before a depoliticized public sphere, Habermas admits the pessimism about the resistance power of civil society and the critical potential of a public dominated by mass media that could undermine the class structures. In Faktizität und Geltung (1992), despite the offensive counterpart of public sphere and civil society, Habermas reiterates his skepticism about the chances of civil society exerting influence on political system before public spheres depoliticized by the manipulative influence of mass-media, and that this depoliticization of public communication would be the nucleus of the culture industry theory. ${ }^{95}$ Finally, in "Political communication in media society” (2006), despite Habermas' updated reading about the growing of media and the role which it plays in the contemporary processes of social and political interaction, the emphasis lies on the negative influence of the dynamics of mass communication and its pathologies in political communication. That is, the use of deliberative model of political public sphere leads to a pessimistic conclusion, the depoliticization of public sphere. The colonization of public sphere, in terms of the market, means the displacement of the category of political public sphere and a critical public sphere

\footnotetext{
94 Cf. Habermas, Strukturwandel der Öffentlichkeit,"Vorwort zur Neuauflage”, p.29. See also: Hauke Brunkhorst, "Critical theory and the analysis of contemporary mass society", in Fred Rush, The Cambridge Companion to Critical Theory, p. 248-79.

${ }^{95}$ Cf. Habermas, Faktizität und Geltung, p. 455.
} 
manipulated and degenerated by the strategies of entertainment media. $^{96}$

However, besides the implicit assumptions about the nucleus of the theory of cultural industry in major works of Habermas, I would like to remind some direct references of Habermas. In an interview published in 1985, "Ein Interview mit New Left Review", Habermas calls attention to the fact that "the critique of mass culture from Adorno should be continued and rewritten". ${ }^{97}$ And in an article published in 2008, "Medien, Märkte und Konsumenten”, by discussing the market and mass-media and its relation with public sphere, Habermas argues that "just as before, Adorno's critique of culture industry is the correct key" (richtige Kern). ${ }^{98}$

These passages help to elucidate the argument that, despite reformulations on the new public spheres, the most recent developments of new mass-media and current diagnosis of pathologies of political communication in public sphere, Habermas does not have a "critical", "emancipated" but only a "manipulated", depoliticized, atrophied, corrupted public sphere, because massmedia are not potential instruments to repoliticization of a critical public sphere. This is the reason for the difficulty in predicting possibilities and developing a satisfactory answer able to recover the normative potential of a critique public sphere, and base it on contemporary social and political institutions. Thus the position resigned, pessimistic and cynical position, the negative view of mass-media, of distrust in the emancipatory potential of mass-media, and that shows how the current position of Habermas has not changed substantially in relation to that original position since Strukturwandel der Öffentlichkeit (1962). Therefore, because there is not a critical public sphere, this issue remains "open”. Maybe that is

\footnotetext{
${ }^{96}$ Cf. Habermas, "Political communication in media society”, p. 9, note 14.

97 Habermas, "Ein Interview mit New Left Review", in Die Neue Unübersichlichkeit. Suhrkamp, 1985, p. 246.

${ }^{98}$ Habermas, "Medien, Märkte und Konsumenten. Die seriöse Presse als Rückgrat der politischen Öffentlichkeit” (2007), in Ach Europa (2008), p. 137.
} 
the reason for the Habermasian repetition that the Adorno's critique of culture industry remains the correct key and that it should be continued and rewritten. I suspect this is a confession that, by not resolving it, this issue - the lack of a critical public sphere - remains suspended, and therefore, it seems to be a task that, 50 years later, remains open. ${ }^{99}$

Referências Bibliográficas

ACTA POLITICA. International Journal of Political Science, v. 40, n. 2-3, 2005.

BAYNES, Kenneth. Communicative ethics, the public sphere and communication media. Critical Studies in Mass Communication, n. 11, p. 315-326, 1994.

BENSON, Rodney. Shaping the public sphere: Habermas and beyond. American Sociologist, n. 40, 175-197, 2009.

BOHMAN, James. Pluralismus, Kulturspezifizität und kosmopolitische Öffentlichkeit im Zeichen der Globalisierung. Deutsche Zeitschrift für Philosophie, v.45, n.6, p. 927-941, 1997. BRUNKHORST, Hauke. Solidarität. Von der Bürgerfreundschaft zur globalen Rechtsgenossenschaft. Frankfurt: Suhrkamp, 2002.

, Critical Theory and the analysis of contemporary mass society. In: RUSH, Fred (Ed.). The Cambridge Companion to Critical Theory. Cambridge/UK: Cambridge University Press, 2004, p. 248-279.

CALHOUN, Craig (Ed.). Habermas and the public sphere. Cambridge/Massachusetts: MIT Press, 1992.

COSTA, Sérgio. As cores de Ercília. Esfera pública, democracia, configurações pós-nacionais. Belo Horizonte: UFMG, 2002.

\footnotetext{
99 This Habermas' reading could be an interesting starting point for empirical researches, for example, of the Communication Sciences and Sociology of Communication.
} 
DEWS, Peter. Habermas: a Critical Reader. Oxford: Blackwell, 1999.

FRASER, Nancy. Rethinking the public sphere: a contribution to the critique of the actually existing democracy. In: CALHOUN, Craig (Ed.). Habermas and the public sphere. Cambridge/Massachusetts: MIT Press, 1992, p. 109.

GARNHAM, Nicholas. The media and the public sphere. In: CALHOUN, Craig (Ed.). Habermas and the public sphere. Cambridge/Massachusetts: MIT Press, 1992, p. 371.

GOMES, Wilson. Esfera pública e media: com Habermas, contra Habermas. In RUBIN, Antonio Albino Canelas; BENTZ, Ione Maria Ghislene; PINTO, Milton José (Org.). Produção e recepção dos sentidos midiáticos. Petrópolis: Vozes, 1998.

. MAIA, Rousiley Celi Moreira. Comunicação e democracia: problemas e perspectivas. São Paulo: Paulus, 2008.

GOODE, Luke. Jürgen Habermas, democracy and public sphere. London: Pluto Press, 2005.

HABERMAS, Jürgen. Theorie des kommunikativen Handelns. Frankfurt: Suhrkamp, 1981.

. Strukturwandel der Öffentlichkeit. Frankfurt: Suhrkamp, 1990. (Vorwort zur Neuauflage).

. Faktizität und Geltung. Frankfurt: Suhrkamp, 1992.

HAHN, Lewis Edwin (Ed.). Perspectives on Habermas. Chicago: Open Court, 2000.

HOHENDAHL, Peter Uwe; SILBERMANN, Marc. Critical Theory, public sphere and culture. Jürgen Habermas and his critics. New German Critique, n.16, p. 89, 1979.

JOHNSON, Pauline. Habermas: rescuing the public sphere. New York: Routledge, 2006.

KELNNER, Douglas. Habermas, the public sphere, and democracy: a critical intervention. In: HAHN, Lewis E. (Ed.). Perspectives on Habermas. Chicago: Open Court, 2000.

KLIER, Peter. Im Dreieck von Demokratie, Öffentlichkeit und Massenmedien. Berlin: Duncker \& Humblot, 1990. 
LUBENOW, Jorge Adriano. A categoria de esfera pública em Jürgen Habermas. João Pessoa: Manufatura, 2012.

. AZEVEDO, Edmilson Alves de; SILVA, Bartolomeu Leite da. Jürgen Habermas: 80 anos. Rio de Janeiro: Tempo Brasileiro, 2010.

MAIA, Rousiley Celi Moreira; CASTRO, Maria Ceres (Org.). Mídia, esfera pública e identidades coletivas. Belo Horizonte: Editora da UFMG, 2006.

OUTHWAITE, William. Habermas: a Critical Introduction. Stanford: Stanford University Press, 1994.

PETERS, Bernhard. Der Sinn von Öffentlichkeit. Frankfurt: Suhrkamp, 2007.

RUSH, Fred (Ed.). The Cambridge Companion to Critical Theory. Cambridge/UK: Cambridge University Press, 2004.

SITTON, John. The limitations of Habermas's social and political argument. In: . Habermas and the contemporary society. New York: Palgrave, 2003, p. 121-140.

SÖHNER, FELICITAS. ENTWICKLUNG DER MASSENMEDIEN UND STRUKTURWANDEL DER MEDIALEN ÖFFENTLICHKEIT BEI HABERMAS. MÜNCHEN: GRIN VERLAG/FERN UNIVERSITÄT HAGEN, 2007.

WINGERT, Lutz; GÜNTHER, Klaus (Ed.). Die Öffentlichkeit der Vernunft und die Vernunft der Öffentlichkeit. Frankfurt: Suhrkamp, 2001. 